Hydrology and Earth System Sciences, 6(3), 515-525 (2002) C C EGS

\title{
The influence of riparian-hyporheic zone on the hydrological responses in an intermittent stream
}

\author{
Andrea Butturini, Susana Bernal, Sergi Sabater and Francesc Sabater \\ Department of Ecology, University of Barcelona, Avd. Diagonal, 64508028 Barcelona, Spain \\ Email for corresponding author andrea@porthos.bio.ub.es
}

\begin{abstract}
Stream and riparian groundwater hydrology has been studied in a small intermittent stream draining a forested catchment for a system representative of a Mediterranean climate. The relationship between precipitation and stream runoff and the interactions between stream water and the surrounding riparian groundwater have been analysed under a wide spectrum of meteorological conditions. The hypothesis that the hydrological condition of the near-stream groundwater compartment can regulate the runoff generation during precipitation events was tested. Stream runoff is characterised by a summer dry period, and precipitation input explained only $25 \%$ of runoff variability over the study period $\left(\mathrm{r}^{2}=0.25\right.$, d.f. $\left.=51, \mathrm{p}<0.001\right)$. The variability of precipitation $v$. stream runoff is explained partly by the hydrogeological properties of the riparian near-stream zone. This zone is characterised by high hydrological conductivity values and abrupt changes in groundwater level in summer. The summer dry period begins with a rapid decrease in near-stream groundwater level, and ends just after the first autumnal rain when the original groundwater level recovers suddenly. Within this period, storms do not cause major stream runoff since water infiltrates rapidly into the riparian compartment until it is refilled during the subsequent winter and spring; then the precipitation explains the $80 \%$ of the stream runoff variability $\left(r^{2}=0.80\right.$, d.f. $\left.=34, p<0.001\right)$. These results suggest that the hydrological interaction between the riparian groundwater compartment and the stream channel is important in elucidating the hydrological responses during drought periods in small Mediterranean streams.
\end{abstract}

Keywords: riparian zone, groundwater hydrology, runoff, intermittent stream, Mediterranean climate

\section{Introduction}

Studies of catchment-stream interactions have recently addressed the effects of the near-stream zones on stream biogeochemistry (Bencala, 1993). "Near-stream" is a general term that includes the riparian and the hyporheic zones, which are transition compartments between the stream and the catchment. Most research on riparian and hyporheic zones has focused on nutrient dynamics (Hill, 2000) as they are of major importance for the protection of stream ecosystems and freshwater resources (Standford, 1998). For instance, riparian zones can reduce the nitrate from groundwater entering the stream and contribute to the mitigation of anthropogenic nitrogen inputs to catchments (Hill, 1996; Komor and Magner, 1996). Strictly, the riparian zone is located along the stream edge and, hydrologically, it is characterised by unidirectional groundwater flux from the hillslope to the stream (Burt, 1997). The hyporheic zone bounds the stream channel and the hydrology is bi- directional due to the continuous mixing between the stream water and groundwater (Duff and Triska, 2000). In practice, however, the separation between the two compartments is purely arbitrary since both are physically connected (Bencala, 2000), and its hydrodynamics are complex since stream water and hillslope groundwater converge. Several theoretical papers (Taha et al., 1997; Serrano and Workmann, 1998; Barlow et al. 2000) and field studies (Morrice et al., 1997; Wondzell and Swanson, 1996; Wroblichy et al., 1998; McDonnell, 1998) have emphasised the importance of hydrological interactions between the stream water and the near-stream at reach scale. On the other hand, hydrogeologists highlight the role of soil moisture (Bras, 1990) and of the spatial hydrological heterogeneity in influencing the runoff generation in catchments (Merz and Bárdossy, 1998; Becker et al., 1999). Although the bank storage effect in moderating the flood peaks is well recognised for large river/floodplain systems (Freeze and 
Cherry 1979), relatively little research has been undertaken to assess the ability of the near-stream zones to control stream runoff in small streams.

In this paper, stream hydrology, riparian-hyporheic groundwater and riparian soil water content have been studied in an intermittent stream draining a forested catchment subject to the Mediterranean discharge regime (Catalonia, north-eastern Spain). The relationship between precipitation and stream runoff as well as the hydrological interaction between stream water and riparian groundwater has been analysed during three years under a wide spectrum of meteorological conditions. It is proposed in this paper, that the hydrological conditions and the hydraulic properties of the near-stream zone provide an important source of variability in the relationship between precipitation input and stream runoff output in intermittent streams.

\section{Study site}

Fuirosos stream is located in a forested catchment $\left(16.2 \mathrm{~km}^{2}\right)$ with altitude ranging between 50 and 770 m..a.s.l., near Barcelona, north-eastern Spain (latitude $41^{\circ} 42^{\prime}$, longitude $2^{0} 34^{\prime}$. Climate is typically Mediterranean with a mean annual temperature range of $3{ }^{\circ} \mathrm{C}$ in January to $24^{\circ} \mathrm{C}$ in August. The riparian study plot is a forested zone, $55 \mathrm{~m}$ long and $18 \mathrm{~m}$ wide located between an agricultural field and the stream. Vegetation is dominated by a plantation of sycamores (Platanus hyspanica) and alders (Aluns glutinosa) near the stream edge. The stream is an intermittent third order stream and the catchment area upstream of the monitoring site in $10.5 \mathrm{~km}^{2}$. The stream channel at this point is 3 to $5 \mathrm{~m}$ wide and is characterised by a steep-pool morphology with large cobbles and boulders. The granite bedrock is located 6 to $13 \mathrm{~m}$ below the ground surface. There are a weathered granite layer 2 to $11 \mathrm{~m}$ thick and a gravel/sandy soil layer 0.8 to $2.8 \mathrm{~m}$ thick overlying the bedrock (Lluis Rivero, personal communication). The saturated hydraulic conductivity $\left(k, \mathrm{~m} \mathrm{~h}^{-1}\right)$ in the riparian area has a high spatial variability. Lower $k$ values occur mainly in the altered granite layer of the hillslope portion of the riparian zone $\left(410^{-4}<k<10^{-3} \mathrm{~m} \mathrm{~h}^{-1}\right)$ and high values occur in the gravelsoil layer close to the stream channel $\left(0.2<k<0.8 \mathrm{~m} \mathrm{~h}^{-1}\right)$.

\section{Material and methods}

\section{STREAM RUNOFF AND PRECIPITATION}

\section{MONITORING}

Stream water level was monitored continuously from $1 / 7 / 98$ to $1 / 7 / 2001$, using a water pressure sensor connected to an automatic sampler (Sigma 900 Max). Continuous stream discharge measurements were obtained from an empirical relationship between the discharge calculated in the field by the "slug" chloride addition method (Gordon et al., 1992) and the corresponding stream water level. The stream water flux during precipitations was calculated by integrating the full storm hydrographs, which includes the rapid runoff, and the slow groundwater components. The estimation of the storm runoff and precipitation input allowed the calculation of the runoff coefficient (R.C.). Precipitation data were recorded continuously at $15 \mathrm{~min}$ intervals from the meteorological station commissioned, in March 1999, on the study site. Previous precipitation data were provided by the Catalan Meteorological Service (SMC) from a meteorological station located $5 \mathrm{~km}$ from the study site. Precipitation intensity $\left(\mathrm{PI}_{15}, 1 \mathrm{~m}^{-2} \mathrm{~h}^{-1}\right)$ is defined as the precipitation recorded in $15 \mathrm{~min}$; the maximum precipitation intensity $\left(\mathrm{PI}_{15 \mathrm{Max}}, 1 \mathrm{~m}^{-2} \mathrm{~h}^{-1}\right)$ is the highest $\mathrm{PI}_{15}$ value recorded during a precipitation event; the average precipitation intensity $\left(\mathrm{PI}_{\mathrm{AV}}, 1 \mathrm{~m}^{-2} \mathrm{~h}^{-1}\right)$ is the ratio between the total precipitation of an event $\left(\mathrm{S}_{\text {prec }}, 1 \mathrm{~m}^{-2}\right)$ and its duration.

\section{GROUNDWATER AND SOIL MOISTURE}

\section{MONITORING}

Riparian groundwater level was monitored in 24 wells arranged in a regular grid $(6 \times 4$ rows $)$ in the riparian plot. Row 1 corresponds to the wells located near the stream edge, and row 4 corresponds to the hillslope wells adjacent to the agricultural field (Fig. 1). The wells were made by installing PVC tubes $(\varnothing 15 \mathrm{~cm})$ at depths ranging from $1 \mathrm{~m}$ (near the stream edge) to $7 \mathrm{~m}$ (near the agricultural field). The wells were perforated uniformly and plugged at the bottom. Groundwater levels in the wells were monitored manually from June 1998 to September 2000. Groundwater level in well $2_{2}$ (located in the riparian area), was monitored continuously using a water pressure sensor connected to a data logger (Campbell CR10X) from June 1998 to July 2001. Groundwater levels in wells $3_{3}$ and $4_{2}$ (located at the hillslope) were monitored continuously from September 1999 to January 2000 (Fig. 1b). Within the riparian plot, perpendicular and parallel hydraulic gradients to the stream channel were calculated to estimate the main flow direction of the groundwater. The perpendicular hydraulic gradient in the hillslope portion of the riparian area (i.e. between rows 4 and 3) is indicated as " $\operatorname{grad} z_{\text {agr }}$ ". The perpendicular hydraulic gradient (indicated as grad $z_{\text {st-perp }}$ ) and the parallel hydraulic gradient (indicated as grad $z_{\text {st-par }}$ ) in the near stream portion have been estimated. Positive perpendicular hydraulic gradient values indicated water movement from the riparian area to the stream; negative values indicated water flow in the opposite direction. 

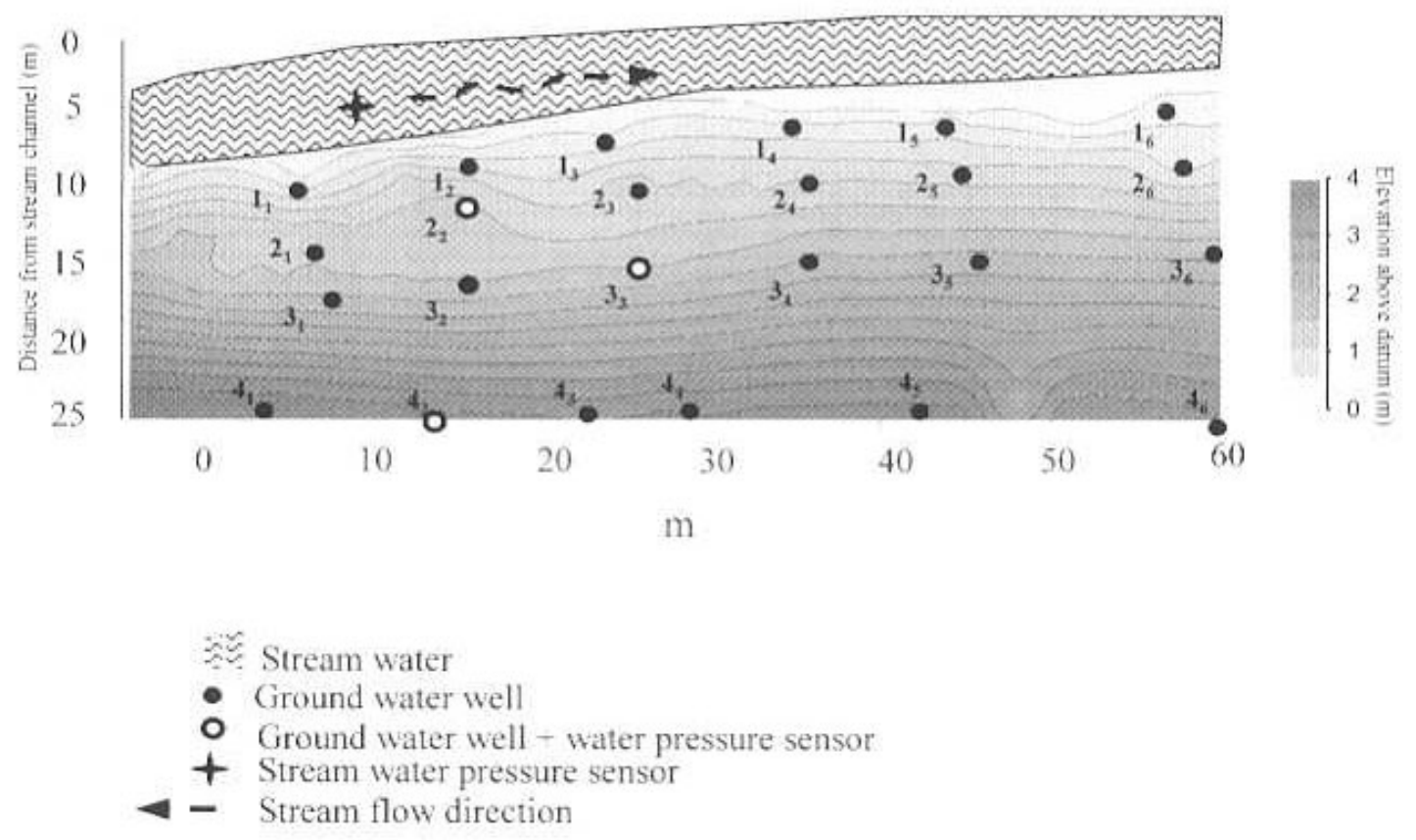

Fig. 1. Cross section (panel a) and vertical view (panel b) of the riparian study site showing the lithology profiles, saturated hydraulic conductivity values $\left(m h^{-1}\right)$ and well locations.

Soil moisture content in the riparian area was monitored continuously from December 1998 to April 2000 by using two TDR probes (Campbell CS615) placed $10 \mathrm{~cm}$ below the soil surface. Soil moisture $(\theta)$ is expressed as percent of the volumetric water content.

\section{Results}

\section{PRECIPITATION REGIME}

Monthly precipitation for the three hydrological years (from July to June) is shown in Table 1 . Annual precipitation during the monitored years averaged $6131 \mathrm{~m}^{-2} \mathrm{y}^{-1}$, with small inter-annual variability but high monthly inter-annual differences. The lowest monthly inter-annual variabilities (c.v. $<18 \%$ ) were recorded in May, September and October. Precipitation occurred $2.5 \%$ of the time and weighted average of rain intensity was $2.71 \mathrm{~m}^{-2} \mathrm{~h}^{-1} .99 .8 \%$ of the rain intensities ranged between 1.6 and $321 \mathrm{~m}^{-2} \mathrm{~h}^{-1}$, the higher values of $\mathrm{PI}_{15 \mathrm{Max}}$ were recorded in August 1998, September 1999 and September 2000 (Fig. 2). In the study period, there were 53 events between 5.8 to $1321 \mathrm{~m}^{-2}$ (Fig. 3), in $94 \%$ of the cases total precipitation was less than $601 \mathrm{~m}^{-2}$. The events selected covered $80 \%$ of the total recorded precipitation, and they were distributed uniformly through the season (32\% in spring, $24.5 \%$ in summer, $23 \%$ in autumn, $21 \%$ in winter). However, the wet periods occurred during autumn and
Table 1. Monthly and inter-annual average precipitation (1 $\mathrm{m}^{-2}$ ) at Fuirosos catchment during the study period

\begin{tabular}{lcccl}
\hline Month & $98 / 99$ & $99 / 00$ & $00 / 01$ & $\begin{array}{l}\text { Average } \\
\text { (c.v.) }\end{array}$ \\
\hline July & 37.2 & 14.6 & 8.2 & $20(76)$ \\
August & 76.2 & 30 & 42.4 & $50(48)$ \\
September & 87.8 & 82.6 & 113.6 & $95(18)$ \\
October & 76.8 & 81.2 & 95 & $84(11)$ \\
November & 6.4 & 52.2 & 21.2 & $26(87)$ \\
December & 147.4 & 31 & 131 & $103(61)$ \\
January & 90.6 & 17 & 131.8 & $80(72)$ \\
February & 0 & 2.8 & 50.4 & $18(160)$ \\
March & 19.4 & 30.6 & 28.6 & $26(23)$ \\
April & 25 & 90.4 & 19.6 & $45(88)$ \\
May & 32.8 & 40.4 & 37.8 & $37(10)$ \\
June & 17.6 & 58.6 & 8.6 & $28(94)$ \\
TOTAL & 617.2 & 531.4 & 689.2 & $613(13)$
\end{tabular}

winter $(30 \%$ of total precipitation occurred during each period) and the dry periods were summer $(21.6 \%)$ and spring (17.7\%) (Table 2). The rainy episodes $\left(\mathrm{S}_{\text {prec }}>40 \mathrm{l} \mathrm{m}^{-2}\right.$, a total of 10 events) occurred in summer (3 episodes), autumn (4) and winter (3); no cases were recorded in spring. 
Table 2. Precipitation amount and duration (Dt), rain maximum intensity $\left(\mathrm{PI}_{\mathrm{Max}}\right)$, rain average intensity $\left(\mathrm{PI}_{\mathrm{Avg}}\right)$, total stream runoff and runoff coefficient (R.C.) of the events monitored during the study period.

\begin{tabular}{|c|c|c|c|c|c|c|}
\hline Day & $\begin{array}{l}\text { Rain } \\
\left(l \mathrm{~m}^{-2}\right)\end{array}$ & $\begin{array}{l}\text { Dt X } \\
\left(l m^{-2}\right)\end{array}$ & $\begin{array}{l}P I_{M a x} \\
\left(l \mathrm{~m}^{-2} 15 \mathrm{~min}^{-1}\right)\end{array}$ & $\begin{array}{l}P I_{\text {Avg }} \\
\left(\mathrm{l} \mathrm{m}^{-2} 15 \mathrm{~min}^{-1}\right)\end{array}$ & $\begin{array}{l}\text { Runoff } \\
\left(l \mathrm{~m}^{-2}\right)\end{array}$ & $\begin{array}{l}O / I \\
(\%)\end{array}$ \\
\hline $07 / 07 / 98$ & 9.5 & 0.8 & 4.5 & 3.2 & $\sim 0^{*}$ & $\sim 0^{* *}$ \\
\hline $14 / 07 / 98$ & 44.9 & 20.0 & 7.2 & 0.6 & 0.002 & 0.01 \\
\hline $11 / 09 / 98$ & 8.8 & 14.0 & 2.8 & 0.2 & $\sim 0$ & $\sim 0$ \\
\hline $23 / 09 / 98$ & 40 & 68.0 & 4.4 & 0.1 & 0.089 & 0.22 \\
\hline $05 / 10 / 98$ & 32 & 10.0 & 4.7 & 0.8 & 0.077 & 0.24 \\
\hline $07 / 10 / 98$ & 24.8 & 22.0 & 6.8 & 0.3 & 0.049 & 0.20 \\
\hline $18 / 10 / 98$ & 11 & 13.0 & 2.5 & 0.2 & 0.035 & 0.32 \\
\hline $02 / 12 / 98$ & 112 & 23.0 & 3.0 & 1.2 & 5.241 & 4.68 \\
\hline $30 / 12 / 98$ & 34 & 15.0 & 3.0 & 0.6 & 0.274 & 0.81 \\
\hline $31 / 12 / 98$ & 31 & 19.5 & 3.4 & 0.4 & 2.448 & 7.90 \\
\hline 09/01/99 & 40.6 & 36.0 & 1.5 & 0.3 & 3.077 & 7.58 \\
\hline $18 / 01 / 99$ & 20 & 38.0 & 2.2 & 0.1 & 1.692 & 8.46 \\
\hline $24 / 03 / 99$ & 8 & 12.0 & 0.4 & 0.2 & 0.044 & 0.55 \\
\hline $28 / 04 / 99$ & 11.8 & 5.5 & 1.2 & 0.5 & 0.038 & 0.34 \\
\hline $22 / 07 / 99$ & 8.4 & 0.8 & 7.8 & 2.8 & $\sim 0$ & $\sim 0$ \\
\hline $12 / 08 / 99$ & 26.8 & 10.0 & 7.2 & 0.7 & $\sim 0$ & $\sim 0$ \\
\hline $14 / 09 / 99$ & 49.6 & 20.0 & 19.4 & 0.6 & 0.006 & 0.01 \\
\hline $19 / 09 / 99$ & 25 & 14.0 & 3.4 & 0.4 & 0.002 & 0.01 \\
\hline $17 / 10 / 99$ & 23.1 & 4.0 & 5.6 & 1.4 & 0.155 & 0.67 \\
\hline 20/10/99 & 45 & 13.0 & 7.8 & 0.9 & 3.713 & 8.25 \\
\hline $12 / 11 / 99$ & 40.8 & 40.0 & 3.6 & 0.3 & 4.022 & 9.86 \\
\hline $15 / 12 / 99$ & 28.6 & 19.0 & 1.6 & 0.4 & 2.442 & 8.54 \\
\hline $28 / 03 / 00$ & 9.2 & 8.0 & 1.0 & 0.3 & 0.030 & 0.32 \\
\hline $31 / 03 / 00$ & 16 & 53.0 & 2.0 & 0.1 & 0.055 & 0.34 \\
\hline $10 / 04 / 00$ & 33 & 19.0 & 1.4 & 0.4 & 1.635 & 4.95 \\
\hline $23 / 04 / 00$ & 7.8 & 7.0 & 4.0 & 0.3 & 0.188 & 2.41 \\
\hline $28 / 04 / 00$ & 30.4 & 18.0 & 3.8 & 0.4 & 0.919 & 3.02 \\
\hline $09 / 05 / 00$ & 16 & 8.0 & 4.6 & 0.5 & 0.043 & 0.27 \\
\hline $22 / 05 / 00$ & 9.4 & 9.0 & 0.6 & 0.3 & 0.072 & 0.77 \\
\hline $06 / 06 / 00$ & 14.2 & 3.0 & 3.6 & 1.2 & 0.109 & 0.77 \\
\hline $10 / 06 / 00$ & 30 & 19.0 & 6.6 & 0.4 & 0.401 & 1.34 \\
\hline $10 / 07 / 00$ & 6.8 & 4.0 & 2.6 & 0.4 & $\sim 0$ & $\sim 0$ \\
\hline $04 / 08 / 00$ & 28.2 & 3.5 & 6.2 & 2.0 & 0.001 & $\sim 0$ \\
\hline $30 / 08 / 00$ & 7.4 & 14.0 & 0.8 & 0.1 & $\sim 0$ & $\sim 0$ \\
\hline $04 / 09 / 00$ & 17.6 & 4.0 & 5.0 & 1.1 & $\sim 0$ & $\sim 0$ \\
\hline $18 / 09 / 00$ & 22.2 & 0.5 & 21.8 & 0.2 & $\sim 0$ & $\sim 0$ \\
\hline $19 / 09 / 00$ & 58.6 & 22.0 & 11.8 & 0.7 & 0.197 & 0.34 \\
\hline $29 / 09 / 00$ & 13.4 & 10.0 & 2.0 & 0.3 & 0.002 & 0.01 \\
\hline $13 / 10 / 00$ & 28 & 12.0 & 1.4 & 0.6 & 0.449 & 1.60 \\
\hline $21 / 10 / 00$ & 37 & 48.0 & 5.2 & 0.2 & 1.639 & 4.43 \\
\hline $21 / 12 / 00$ & 127.6 & 92.0 & 6.4 & 0.3 & 9.437 & 7.40 \\
\hline $12 / 01 / 01$ & 131.6 & 54.0 & 5.2 & 0.6 & 78.658 & 59.77 \\
\hline $14 / 02 / 01$ & 15.8 & 9.0 & 1.6 & 0.4 & 0.063 & 0.40 \\
\hline $15 / 02 / 01$ & 9.6 & 3.0 & 3.6 & 0.8 & 0.237 & 2.47 \\
\hline $24 / 02 / 01$ & 24.2 & 29.0 & 1.0 & 0.2 & 3.111 & 12.86 \\
\hline 08/03/01 & 5.8 & 3.0 & 1.2 & 0.5 & 0.020 & 0.34 \\
\hline $12 / 03 / 01$ & 6 & 3.5 & 3.0 & 0.4 & 0.033 & 0.55 \\
\hline $29 / 03 / 01$ & 16.8 & 5.0 & 6.0 & 0.8 & 0.038 & 0.22 \\
\hline $30 / 04 / 01$ & 8.6 & 5.0 & 2.8 & 0.4 & 0.050 & 0.58 \\
\hline $01 / 05 / 01$ & 12 & 5.0 & 3.4 & 0.6 & 0.073 & 0.61 \\
\hline $04 / 05 / 01$ & 18.9 & 29.0 & 3.0 & 0.2 & 0.163 & 0.86 \\
\hline $18 / 05 / 01$ & 7.2 & 2 & 8.8 & 3.60 & 0.037 & 0.52 \\
\hline $10 / 06 / 01$ & 7 & 20 & 8.8 & 0.35 & 0.027 & 0.38 \\
\hline
\end{tabular}

(*) stream runoff was nearly nil and the subsequent R.C. was considered virtually nil (**) For graphical purpose, R.C. nil values were converted to $10^{-5}$ (see Fig. 7). 


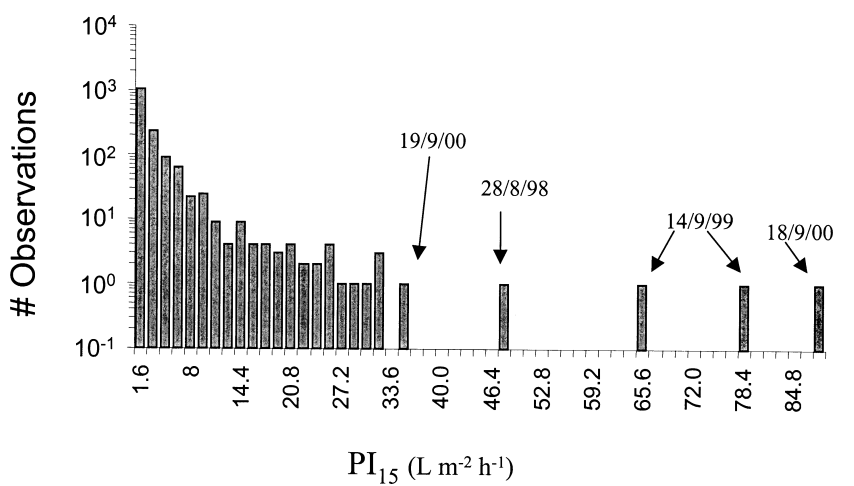

Fig. 2. Frequency distribution of the rain intensity during the study period $(n=1536)$.

\section{HYDROLOGICAL REGIME}

The stream basal discharge regime showed a marked seasonal pattern characterised by a long dry period from June until the first major autumnal storm in late SeptemberOctober (Fig. 3). Usually, the dry period begins at the end of May and, throughout June, water flow was nearly nil and surface water was stored mainly in pools within the stream bed. From July to late September, the stream channel was completely dry. At baseflow conditions, the discharge ranged from $7 \mathrm{l} \mathrm{s}^{-1}$ (in spring) to $201 \mathrm{~s}^{-1}$ (in winter). When precipitation ranged from 6 to $601 \mathrm{~m}^{-2}$, discharge peaks were between 40 and $2001 \mathrm{~s}^{-1}$. Exceptionally high discharge peaks coincided with rainfall higher than $1001 \mathrm{~m}^{-2}$ :
December $1998\left(\mathrm{~S}_{\text {prec }}=1121 \mathrm{~m}^{-2}, \mathrm{Q}_{\text {peak }}=13151 \mathrm{~s}^{-1}\right)$, December $2000\left(\mathrm{~S}_{\text {prec }}=1281 \mathrm{~m}^{-2}, \mathrm{Q}_{\text {peak }}=829 \mathrm{~L} \mathrm{~s}{ }^{-1}\right)$ and January 2001 $\left(\mathrm{S}_{\text {prec }}=1321 \mathrm{~m}^{-2}, \mathrm{Q}_{\text {peak }}=260001 \mathrm{~s}^{-1}\right)$ (Fig. 3).

Storm runoff occurred only for $9 \%$ of the time, but contributed to $60 \%$ of the total discharge volume. Annual runoff coefficients ranged from 5\% (1998/99) to 17\% (2000/ $01)$. In a more detailed analysis, individual storm runoff coefficients (R.C.) averaged $3.1 \% \pm 8.5$ following a clear seasonal pattern. The highest R.C. occurred in autumn and winter, approaching $10 \%$ (with a peak of $60 \%$ during the flood of January 2001), while the lowest coefficients (less than $0.1 \%$ in several cases, Table 2) occurred during the dry period from June to September. The high variability of the R.C. reflected a weak relationship between the precipitation input and the stream runoff (log-log relationship, $\mathrm{r}^{2}=0.25$, d.f. $\left.=51, \mathrm{p}<0.001\right)$.

\section{GROUNDWATER HYDROLOGY AND RIPARIAN SOIL} MOISTURE

The temporal dynamics of the average groundwater levels in each row within the riparian plot showed that the hillslope and the near-stream zone had different hydrological patterns. In the hillslope zone (rows 3 and 4), groundwater levels changed continuously following a clear seasonal pattern with high levels from November to April (Fig. 4a). In this zone, the main groundwater flow was perpendicular to the stream

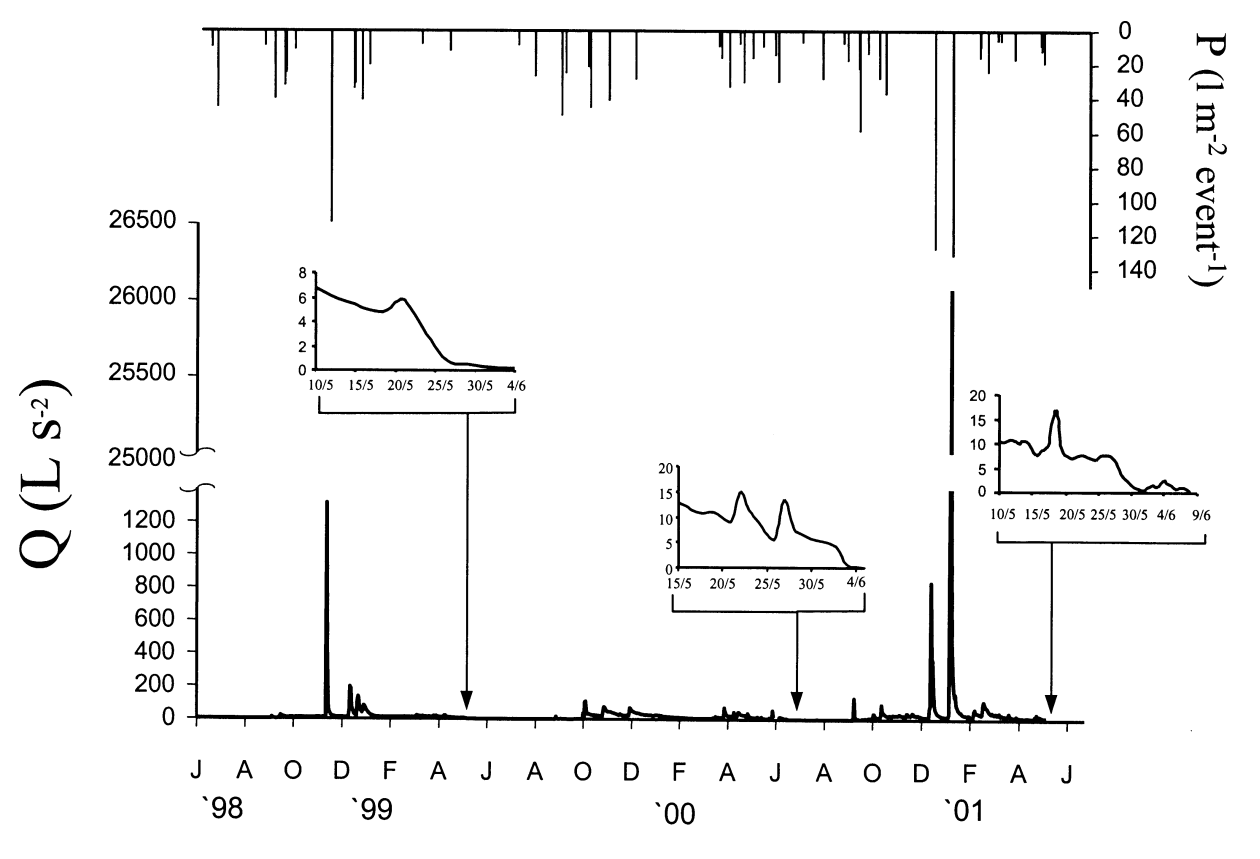

Time

Fig. 3. Temporal dynamic of discharge and associated precipitation events in Fuirosos during the study period. Insets show the drying of the stream channel. 


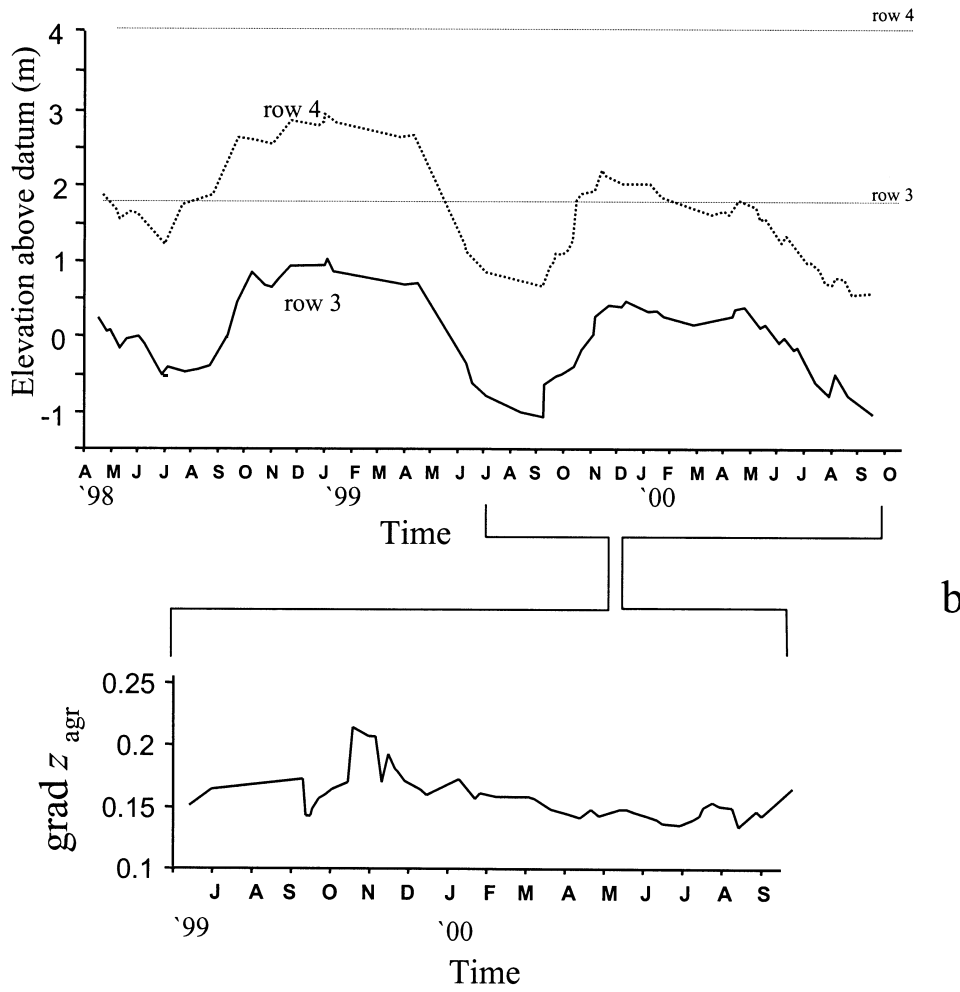

Fig. 4. Temporal dynamics of average groundwater level in the hillslope riparian portion. Horizontal dotted rows shows the soil elevation near the well in each row. Panel b shows the temporal pattern of the hydraulic gradient between rows 3 and 4 during a selected study period.

channel. The hydraulic gradient was steep and nearly constant over the study period ( $\left.\operatorname{grad} z_{\text {agr }}=0.17 \pm 0.03 \mathrm{sd}\right)$ with a maximum to 0.21 early in autumn, shortly after the dry period (Fig. 4b). On the other hand, water heads in wells near the stream channel (rows 2 and 1) strongly covaried in time $\left(\mathrm{r}^{2}=0.95\right.$, d.f. $\left.=62, \mathrm{p}<0.001\right)$ and followed the stream level pattern from late autumn to spring. After this time, the water level started to decline (at a rate of $0.2 \mathrm{~cm} \mathrm{~h}^{-1}$ ) from 15 th to the 30th of June. Throughout July, the water level decreased to $0.7 \mathrm{~m}$ below the stream bed and consequently stream water pools disappeared. The hydrological deficit periods were interrupted suddenly by the first autumnal rainy event, and the groundwater immediately recovered its level in the near stream portion (at a rate of $10 \mathrm{~cm} \mathrm{~h}^{-1}$ ). In this portion of the riparian plot, the groundwater main flux at basal discharge was parallel to the stream channel since the absolute value of $\operatorname{grad} z_{\text {st-par }}(0.009 \pm 0.002)$ was higher than $\operatorname{grad} z_{\text {st-perp }}(-0.002 \pm 0.007)$. The negative values of the grad $z_{\text {st-perp }}$ indicated that there was a slight water flux from the stream channel to the riparian area.

Due to the abrupt changes in water levels in the nearstream riparian zone, the grad $z_{\text {st-perp }}$ was subjected to drastic changes during precipitation. High negative gradients were recorded during the rainfall episodes of the dry periods and during the flashy winter episodes (December 1998 and January 2001). Meanwhile, positive gradients were recorded during the recession curves after winter storms (Fig. 5b). The influence of the stream water on the riparian groundwater was evident during the transition period from dry to wet conditions. Figure 6 shows the temporal dynamics of stream and groundwater level from the 14th of September 1999 to 30th of January 2000. Shortly after the rainfall, the stream water recharged the surrounding riparian area. Groundwater level in rows 2 and 3 took 12 hours and 7 days respectively to recover and mixing between stream water and the hillslope groundwater occurred along row 3 (10 $\mathrm{m}$ from the stream channel, Fig. 6 , contour plot 1$)$. The stream recharge period lasted for two months and was followed by a period of hillslope groundwater recharge from November to April. During this latter period, hillslope groundwater recharge predominated over stream recharge; in consequence, the mixing between stream water and hillslope groundwater moved back to between rows 2 and 1. 

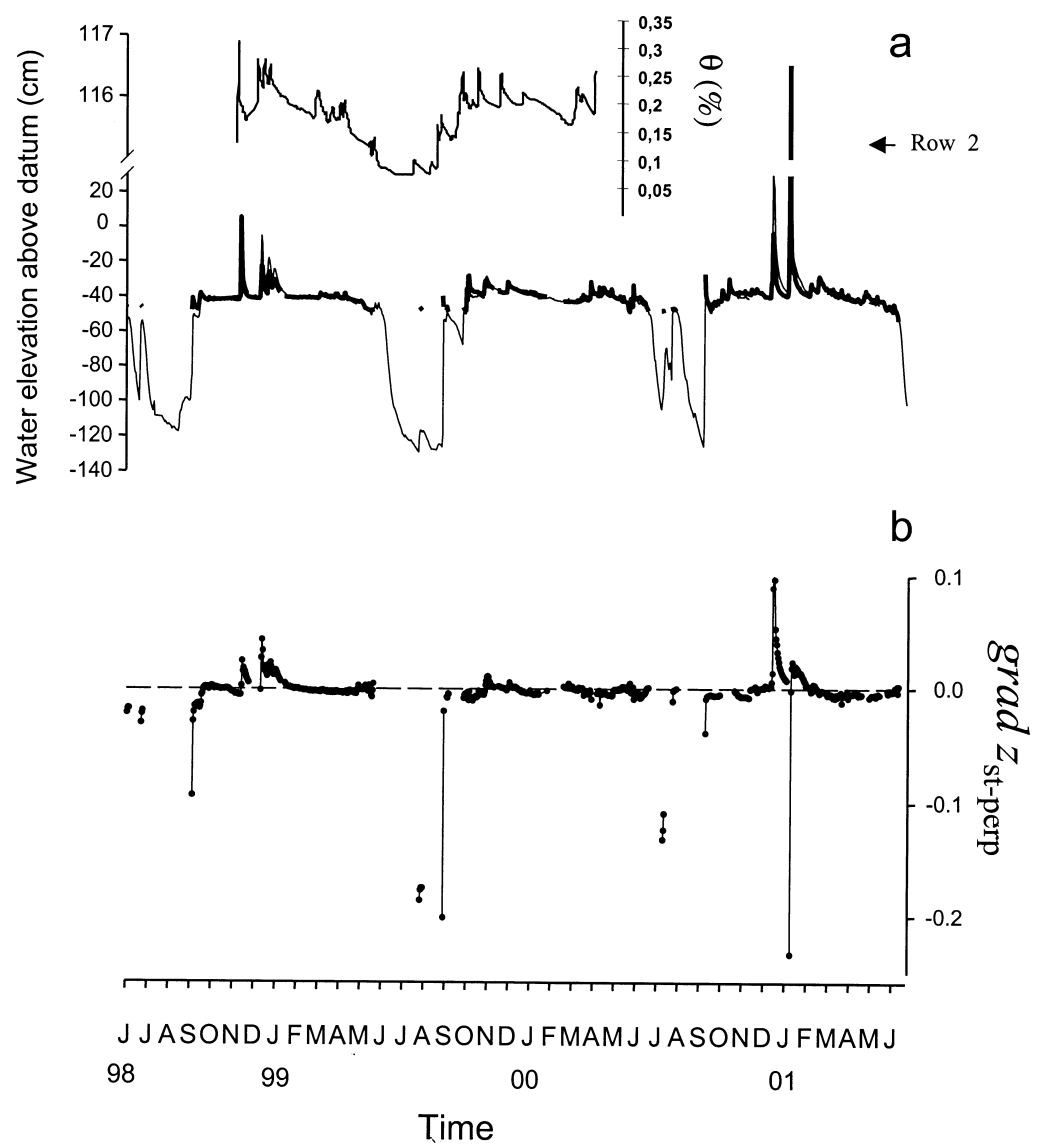

Fig. 5. Temporal dynamics of the stream (bold solid line), near stream groundwater level (row 2, thin solid line) and volumetric water content in riparian soil. Panel b shows the near-stream perpendicular hydraulic gradient.

The water content of the riparian soil followed a clear seasonal pattern with maxima in winter (10-22\%, with peaks up to $30 \%$ during storms), and a gradual shift to dry conditions in summer $(10 \%)$, afterwards, the soil moisture content increases gradually until January with peaks during the rainfall events (Fig. 5, inset).

\section{Discussion}

\section{THE STREAM-RIPARIAN HYDROLOGY}

The present study shows that the stream-aquifer interface is a dynamic system distinguished by a seasonal pattern with three hydrological sub-periods. The cyclic occurrence of the dry period with rapid increase of the groundwater level determines key changes in the riparian near-stream groundwater hydrology. This induces the development of reverse fluxes during the summer and autumn rain events and the subsequent increase of the stream water contribution over the riparian groundwater. Several studies revealed a decline in the contribution of the stream water to the hyporheic water at high discharges (Legrand-Marq and
Ladelout, 1985; D'Angelo et al., 1993; Wondzell and Swanson, 1996; Wroblichy et al., 1998). This general pattern results from observations of stream-aquifer systems with high groundwater level that have limited the recharge of the aquifer with stream water (Harvey and Wagner, 2000). In the present case, the positive near-stream hydraulic gradients (i.e. grad $z_{\text {st-perp }}>0$ ) have been recorded during stream recession for winter storm, indicating a contraction of the hyporheic zone after the peak discharge. Nevertheless, high negative near-stream gradients (i.e. grad $z_{\text {st-perp }}>0$ ) observed during summer and flashy winter episodes coupled to the high hydraulic conductivity in the near stream riparian portion determines rapid water infiltration and high nearstream groundwater fluxes. This pattern is similar to that observed during occasional storms in ephemeral streams in arid regions (Moench and Kisiel, 1970; Abdulrazzak and Morel-Seytoux, 1983). The increase of the hydraulic gradient in the hillslope portion of the riparian plot (i.e. grad $z_{\text {agr }}$ ) during the stream recharge period, suggested a low hydraulic connectivity in this riparian portion during the dry and the stream recharge periods. 


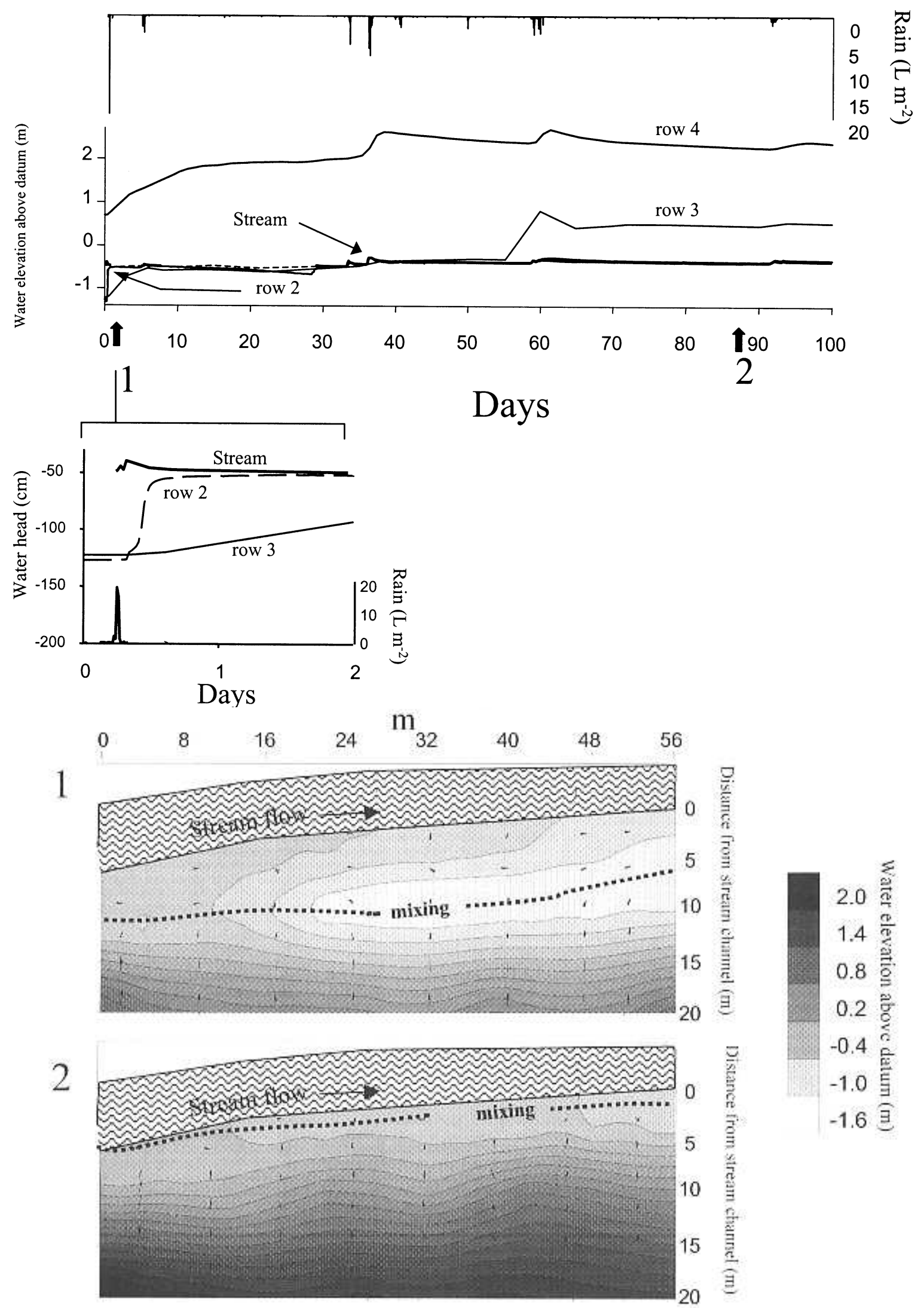

Fig. 6. Detailed temporal pattern of the stream, and groundwater levels from $14^{\text {th }}$ September 1999 to $30^{\text {th }}$ January 2000. Plots 1 and 2 show the groundwater surface contour and gradient vectors during stream recharge (contour 1) and the hillslope recharge (contour 2) periods. 


\section{INTERACTION BETWEEN RIPARIAN HYDROLOGY}

\section{AND STREAM RUNOFF}

The rapid stream water infiltration, in the surrounding groundwater riparian compartment, during the summer rain episodes, determines that storm hydrographs are damped, and that runoff exports are much lower than those generated by similar rain episodes reported when the near-stream compartment is under wet hydrological conditions (from October to the first half of June). Therefore, the water availability in the riparian area affected the relationship between rainfall inputs and stream runoff. Indeed, stream runoff shows a good correlation with the rain input after the riparian near-stream compartment is refilled with stream water. In those cases, rain input accounts for $80 \%$ of the total stream runoff variability (log-log relationship, $\mathrm{r}^{2}=0.80$, d.f. $=34, \mathrm{p}<0.001)$.

Although an increase in the investigation at reach scale of hydrological and biogeochemical interactions at the stream-riparian-aquifer interface, the role of the hydrological features of hyporheic-riparian compartment in regulating stream runoff at catchment scale in small streams is poorly studied. The limited information available is linked to the fact that most of the hydrological studies are carried out in very small catchments (Kirnabauer and Hass, 1998. AA.VV. 2001) with small storage compartments and/or in humid regions where rainfall exceeds evapotraspiration (Pearce $e t$ al., 1986), and the groundwater table easily reaches the ground surface during much of the time. Few studies have combined groundwater table monitoring with catchment runoff measurements. Evans et al. (1999) showed that high stream flows in a peat catchment occurred at times of high groundwater table, and no discharge peaks were associated with low groundwater table. However, there is not a specific description of the near-stream groundwater compartment in this study. On the other hand, Ceballos and Schnabel (1998) have related the variability of the runoff responses in a small semi-arid catchment to antecedent moisture conditions of the valley bottom sediments. In this study, although the role of the unsaturated bottom sediment in buffering the stream runoff remains unclear, the runoff/rain relationship is clearly discernible when near channel sediments are saturated.

Water storage in soil, coupled with the hillslope topography, is an important variable to explain the runoff variability in catchments' hydrological studies (Bras, 1990; Anderson and Burt, 1990). In very small temperate catchments (less than $0.05 \mathrm{~km}^{2}$ ), low runoff is reported under dry soil moisture conditions (Avila, 1988). In Fuirosos, the annual riparian soil moisture pattern showed gradual changes, which contrasted with the abrupt changes observed in near-stream groundwater. In addition, the runoff data obtained under similar riparian soil moisture conditions showed different behaviour. For example, runoff data obtained in late spring (May and June, just before the hydrological deficit period), with riparian soil moisture ranging between $18 \%$ and $10 \%$ fitted well the log-log rainrunoff model (Fig. 7, open circles); whereas, runoff data of late September and early October (when the hydrological deficit period was not terminated), within the same soil moisture range, were outliers into the log-log rain-runoff model (Fig. 7, open diamond). This result suggested that, in Fuirosos, the interactions between soil moisture conditions, hillslope topography and rainfall intensity, might help to explain the unexplained variability of log-log rainrunoff model $(20 \%)$ once the near-stream groundwater recovery reached its level (circle symbols in Fig. 7). This was evident comparing the runoff generated during the two rainy events recorded (21/12/00 and 15/01/01). Although these rains had similar total precipitation, the $\mathrm{PI}_{\mathrm{Avg}}$ in the second event was nearly twice the first one. The short interstorm duration (25 days), and the increase of the soil moisture content in the forest floor (from $14 \%$ to $28 \%$, unpublished data) favoured the formation of a flashy hydrograph during the second event, and the R.C. from the first to the second one shifted from $7.4 \%$ to $60 \%$ (Table 2). The present study suggests that the stream-aquifer system can be a key factor in regulating the stream runoff in an intermittent Mediterranean stream subjected to cyclic and rapid groundwater table changes during a hydrological year. The consequence of this finding is that, to improve the

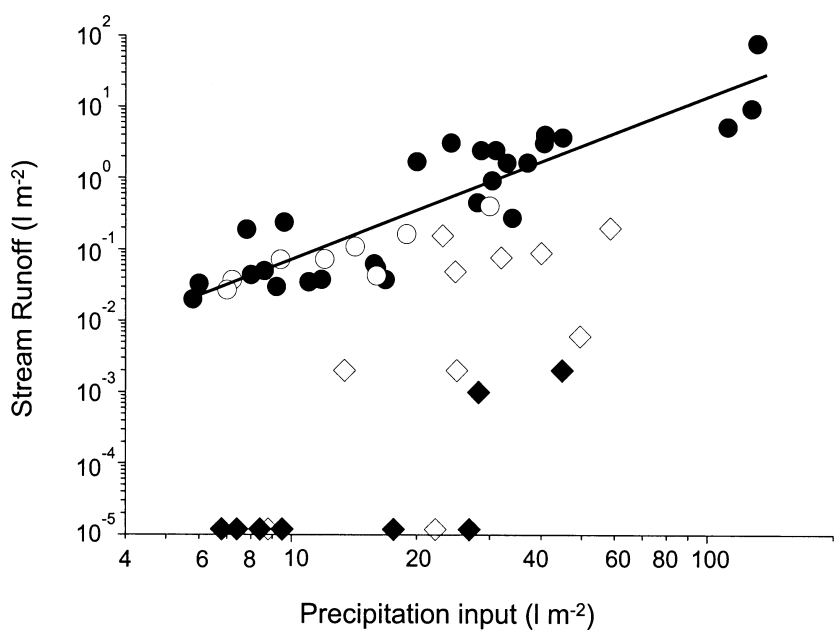

Fig. 7. Log-log relationship between precipitation inputs and stream runoff exports. Circles correspond to the data collected under normal hydrological conditions in the near-stream groundwater compartment $\left(r^{2}=0.8, g . f .=34, p<0.001\right)$; diamonds correspond to the data collected during drought periods. Open circles and open diamonds correspond to the data collected under similar riparian soil moisture conditions. 


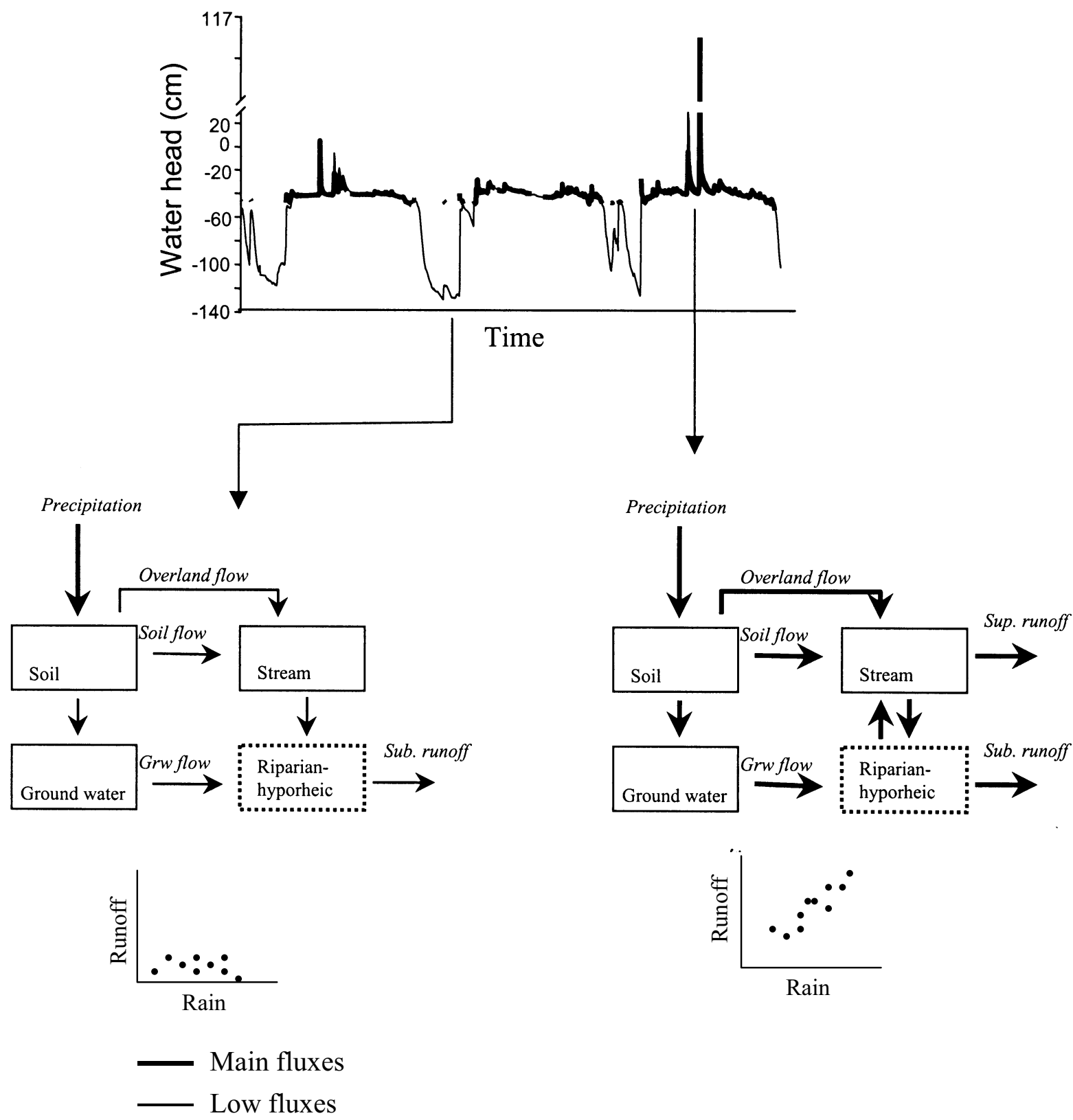

Fig. 8. Box representation of the hydrological components and fluxes in catchment including the riparian-hyporheic compartment during precipitation under dry (on the left) and wet (on the right) near-stream hydrological conditions. The evapotranspiration flux is considered to be nil during precipitations.

quality of runoff simulations in intermittent streams in Mediterranean and semi-arid regions, catchment models should include a riparian near-stream compartment (Fig. 8). The introduction of an interface compartment, between groundwater and stream compartments, enhances the complexity of the catchment models since the number of hydrological parameters increases, and the bi-directional water fluxes between stream and near-stream compartments should be considered (Harvey and Wagner, 2000).

\section{Acknowledgement}

E. Nin, A. Bombí (Diputació de Barcelona, Servei Parcs Naturals) and J. Cerrato-Gallego are thanked for their support in the field; also Colin Neal, the INCA project partners and two anonymous reviews for constructive comments. This research was supported by funds provided by European Community (NICOLAS project, ENV4-CT970395 and INCA projects EVK1-1999-00011). 


\section{References}

Abdulrazzak, M.J. and Morel-Seytoux, H.J., 1983. Recharge from an ephemeral stream following wetting front arrival to water table. WaterResour.Res., 19, 194-200.

Anderson, M.G. and Burt, T.P., 1990. Process Studies in Hillslope Hydrology. Wiley, Chichester, UK.

Avila, A., 1988. Balanc d'aigua i nutrients en una conca d'alzinar del Montseny. Estudis monografics 13. Diputació de BarcelonaServei de Medi Ambient, 219 pp.

AA.VV., 2001. In: Runoff generation and implications for river basin modelling, C. Leiburgut, S. Uhlenbrook and J. McDonnell (Eds.), Procceding of the international workshop on runoff generation and implications for river basin modelling 9-12 October 2000, Freiburg i. Br. Germany, Institut fur Hydrologie der Universitat Freiburg i.Br.

Barlow, P.M., De Simone, L.A. and Moench, A.F., 2000. Aquifer response to stream stage and recharge variations. I. Analytic step-response function. J. Hydrol., 230, 192-210.

Becker, K.E., Bloschl, G. and Hall, A., 1999. Land surface heterogenity and scaling in hydrology. Preface, J. Hydrol., 217, 169-170.

Bencala, K.E., 1993. A perspective on stream-catchment connections, J. N. Amer. Benthol. Soc., 12, 44-47.

Bencala, K.E., 2000. Hyporheic zone hydrological processes. Hydrol. Process., 14, 2797-2798.

Bras, R.L., 1990. Hydrology: an introduction to hydrologic sciences. Addison-Wesley, New York.

Burt T.P., 1997. The hydrological role of floodplains within the drainage basin system. In: Buffer zones: their processes and potential in water protection, N.E. Haycock, T.P. Burt, K.W.T. Goulding and G. Pinay (Eds.) Proceeding of the international Conference on Buffer Zones, September 1996. (Eds., Quest Environmental, U.K. 21-32.

Ceballos, A. and Schnabel, S., 1998. Hydrological behaviour of a small catchment in the dehesa landuse system (Extremadura, SW Spain). J. Hydrol., 210, 146-160.

D’Angelo, D.J., Webster, J.R., Gregory, S.V. and Meyer, J.L., 1993. Transient storage in Appalachian and cascade mountain streams as related to hydraulics characteristics. J. N. Amer. Benthol. Soc., 11, 341-349.

Duff, J.H. and Triska, F.J., 2000. Nitrogen Biogeochemistry and surface-subsurface exchange in streams, In: Streams and ground water, J.B. Jones and P.J. Mulholland, (Eds.), Academic Press, San Diego, USA, 197-220.

Evans, M.G., Burt, T.P., Holden, J. and Adamson, J.K., 1999. Runoff generation and water table fluctuation in blanket peat: evidence from UK data spanning the dry summer of 1995. J. Hydrol., 221, 141-160.

Freeze, R.A. and Cherry, J.A., 1979.Ground water. Prentice-Hall Inc. Englewood Cliff. USA.

Gordon N.D., McMahon, T.A. and Finlayson, B.L., 1992. Stream hydrology. An introduction for ecologists. Prentice Hall, New Jersey, USA.
Harvey, J.W. and Wagner, B.J., 2000. Quantifying hydrologic interactions between streams and their subsurface hyporheic zones. In: Streams and ground water, J.B. Jones and P.J. Mulholland (Eds.) Academic Press, San Diego, USA. 3-44.

Hill, A.R., 1996. Nitrate removal in stream riparian zones, J. Environ. Qual., 25, 743-755.

Hill, A.R., 2000. Stream Chemistry and riparian zones, In: Streams and ground water, J.B. Jones and P.J. Mulholland (Eds.), Academic Press, San Diego, USA. 83-110.

Kirnabauer, R. and Hass, K., 1998. Observations on runoff generation mechanisms in small Alpine catchment. In: Hydrology, water resources and ecology in headwaters. K. Kovar, U. Tappeneir, N.E. Peters and R.G. Craig (Eds.) IAHS Publication no. 248, 239-246.

Komor, S.C. and Magner, J.A. , 1996. Nitrate in ground water and water sources used by riparian trees in agricultural watershed: a chemical and isotopic investigation in southern Minnesota, Water Resour. Res., 32, 1039-1050.

Legrand-Marq, C. and Ladelout, H., 1985. Longitudinal dispersion in a forest stream. J. Hydrol., 78, 317-324.

McDonnell, J., McGlynn, B.L. and Kendall, K., 1998. The role of near-stream riparian zones in the hydrology of steep upland catchment. In: Hydrology, water resources and ecology in headwaters. K. Kovar, U. Tappeneir, N.E. Peters and R.G. Craig (Eds.) IAHS Publication no. 248, 451-458.

Merz, B. and Bárdossy, A., 1998. Effects of spatial variability on the rainfall runoff processes in a small loess catchment. $J$. Hydrol., 212-213, 304-314.

Moench, A.F. and Kiesel, C.C., 1970. Application of the convolution relation to estimating recharge from an ephemeral stream. Water Resour. Res., 6, 1087-1094.

Morrice, J.A., Vallet, H.M., Dahm, C.N. and Campana, M.E., 1997. Alluvial characteristics, groundwater-surface water exchange and hydrological retention in headwater streams. Hydrol. Process., 11, 253-267.

Pearce, A.J., Stewart, A.J. and Sklash, M.G., 1986. Storm runoff generation in humid headwater catchments. 1 . Where does the water come from? Water Resour. Res., 22, 1263-1272.

Serrano, S.E. and Workmann, S.R., 1998. Modelling transient stream/aquifer interaction with non-linear Boussinesq equation and its analytical solution, J. Hydrol., 206, 245-255.

Standford, J.A., 1998. Rivers in the landscape: Introduction to the special issue on riparian and ground water ecology, Freshwater Biol., 40, 402-406.

Taha, A., Gresillon, J.M. and Clothier, B.E., 1997. Modelling the link between hillslope water movement and stream flow: application to a small Mediterranean forested watershed. $J$. Hydrol., 203, 11-20.

Wondzell, S.M. and Swanson, F.J., 1996. Seasonal and storm dynamics of the hyporheic zone of a $4^{\text {th }}$-order mountain steam. I: hydrological processes, J. N. Amer. Benthol.Soc., 15, 3-19.

Wroblichy, G.J., Campana, M.E., Valett H.M. and Dahm C.N., 1998. Seasonal variation in surface-subsurface water exchange and lateral hyporheic area of two stream-aquifer systems, Water Resour. Res., 34, 317-328. 
